\title{
Dose Response of Weed Seeds, Plant-Parasitic Nematodes, and Pathogens to Twelve Rates of Metam Sodium in a California Soil
}

\author{
Susanne Klose and Husein A. Ajwa, Department of Plant Sciences, University of California Davis, 1636 East Alisal \\ Street, Salinas, CA 93905, USA; Greg T. Browne, USDA-ARS, Crops Pathology and Genetics Research Unit, De- \\ partment of Plant Pathology, University of California Davis, Davis, CA 95616, USA; Krishna V. Subbarao, De- \\ partment of Plant Pathology, University of California Davis, 1636 East Alisal Street, Salinas, CA 93905, USA; \\ Frank N. Martin, USDA-ARS, 1636 East Alisal Street, Salinas, CA 93905, USA; Steve A. Fennimore, Department \\ of Plant Sciences, University of California Davis, 1636 East Alisal Street, Salinas, CA 93905, USA; and Becky B. \\ Westerdahl, Nematology Department, University of California Davis, Davis, CA 95616
}

\begin{abstract}
Klose, S., Ajwa, H. A., Browne, G. T., Subbarao, K. V., Martin, F. N., Fennimore, S. A., and Westerdahl, B. B. 2008. Dose response of weed seeds, plant-parasitic nematodes, and pathogens to twelve rates of metam sodium in a California soil. Plant Dis. 92:1537-1546.

Metam sodium (sodium $\mathrm{N}$-methyl dithiocarbamate, metam-Na) is widely used in agricultural and floricultural production for controlling soilborne plant pathogens, parasitic nematodes, and weeds. It undergoes rapid decomposition to the biocide methyl isothiocyanate (MITC) in moist soils. In this study, the efficacy of 12 concentrations of metam-Na (10 to $2,650 \mu \mathrm{mol} \mathrm{kg}{ }^{-1}$ soil) to control seeds or tubers of five major weed species, three soilborne pathogens, and one parasitic nematode was evaluated in a sandy loam soil under controlled conditions. Soils were exposed to the fumigant in microcosms for $24 \mathrm{~h}$ at 10 and $20^{\circ} \mathrm{C}$. Generation and dissipation curves of MITC in soil under controlled conditions showed that MITC concentrations in soils were highest $2 \mathrm{~h}$ after metam-Na application and decreased steadily over the 24-h incubation period. After $24 \mathrm{~h}$, remaining MITC concentrations in soil microcosms at 10 and $20^{\circ} \mathrm{C}$ were 53 and $38 \%$ of the original amount applied, respectively, indicating a $20 \%$ reduction in MITC dissipation at the lower soil temperature. Logistic dose-response models were used to estimate the effective concentration necessary to reduce soil pest viability by $50\left(\mathrm{LC}_{50}\right)$ or $90\left(\mathrm{LC}_{90}\right)$ percent under both temperatures. Seed of Portulaca oleracea, with $\mathrm{LC}_{90}$ values of $\leq 1,242 \mu \mathrm{mol} \mathrm{kg} \mathrm{kg}^{-1}$ soil, was the most sensitive to soil fumigation with metam-Na, followed by Polygonum arenastrum with $\mathrm{LC}_{90}$ values of $\leq 1,922 \mu \mathrm{mol} \mathrm{kg}{ }^{-1}$ soil. At $10^{\circ} \mathrm{C}$ fumigation temperature, metam-Na at the highest dose

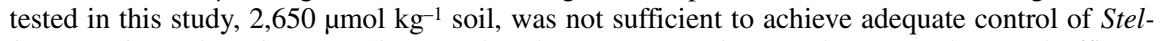
laria media and Malva parviflora seed and Cyperus esculentus tubers. Weed control efficacy (average reduction in $\mathrm{LC}_{90}$ values) of metam-Na was between 25 and $60 \%$ higher if soils were fumigated at $20^{\circ} \mathrm{C}$ compared with $10^{\circ} \mathrm{C}$, with the exception of M. parviflora. Phytophthora cactorum and Pythium ultimum were more sensitive to soil fumigation with metam-Na $\left(\mathrm{LC}_{90} \leq 165\right.$ $\mu \mathrm{mol} \mathrm{kg}{ }^{-1}$ soil) than Verticillium dahliae $\left(\mathrm{LC}_{90} \leq 737 \mu \mathrm{mol} \mathrm{kg}{ }^{-1}\right.$ soil). The nematode Tylenchulus semipenetrans was highly sensitive to soil fumigation with metam-Na $\left(\mathrm{LC}_{90} \leq 98 \mu \mathrm{mol} \mathrm{kg}^{-1}\right.$ soil), and the efficacy of control increased by $30 \%$ if soil was fumigated at $20^{\circ} \mathrm{C}$ compared with $10^{\circ} \mathrm{C}$. In this sandy loam soil, metam-Na at a concentration of $850 \mu \mathrm{mol} \mathrm{kg}{ }^{-1}$ reduced the viability of Portulaca oleracea and Polygonum arenastrum seeds, C. esculentus tubers, and all soilborne pathogens and parasitic nematodes tested by $90 \%$ at $20^{\circ} \mathrm{C}$ after $24 \mathrm{~h}$ exposure. These results indicate that metam-Na can provide effective pest and disease control at maximum label rate for the commercial formulation, but there was a reduction in efficacy at low temperature.
\end{abstract}

Additional keywords: soil disinfestation

Soilborne fungi and oomycete plant pathogens, such as Fusarium oxysporum, Verticillium dahliae, Pythium spp., and Phytophthora cactorum, as well as plantparasitic nematodes, cause severe diseases on many economically important crops, including strawberries, melons, vegetables,

Corresponding author: Susanne Klose

E-mail: sklose@ucdavis.edu

Accepted for publication 29 July 2008.

doi:10.1094/PDIS-92-11-1537

(C) 2008 The American Phytopathological Society
Dazomet (a.i. tetrahydro-3,5-dimethyl- $2 H$ 1,3,5-thiadiazine-2-thione) have been widely used in the United States and worldwide for soil disinfestation $(10,12$, 17,21). In 2005, around 5.9 million $\mathrm{kg}$ of metam-Na were used for preplant fumigation of agricultural soils in California, and the continuing decline in methyl bromide use due to the requirements of the Montreal Protocol will likely increase the use of this fumigant in the future (California DPR, 2006 at http://www.cdpr.ca.gov/docs/ pur/pur05rep/top100_ais.pdf). Metam-Na is a liquid formulation commonly applied to soil at a rate of 350 to 700 liters ha ${ }^{-1}$ (120 to $240 \mathrm{~kg}$ a.i. ha ${ }^{-1}$ ) by chemigation (e.g., in water applied through sprinklers or drip systems, in flood basin, or in furrows) or by shank injection. If applied to moist soil, about $90 \%$ of the active ingredient is transformed into gaseous methyl isothiocyanate (MITC), which possesses fungicidal, nematicidal, insecticidal, and herbicidal properties $(18,31,32)$. Other gaseous degradation products are carbon disulfide, carbonyl sulfide, and hydrogen sulfide, which contribute to a minor extent to pesticidal activities $(18,31,32)$. The generation and dissipation rate of MITC in soil follows first-order degradation kinetics and is governed by microbial, physical, and chemical processes $(15,18,44)$. Microbial degradation of MITC-generating pesticides is affected by soil properties such as soil moisture, temperature, soil $\mathrm{pH}$, and salinity $(1,43)$. Increased fumigant degradation has been observed with increasing temperature due to increased microbial metabolism and enhanced chemical degradation $(32,38$, $41,44)$. Fumigant efficacy to control various soilborne pests depends on the concentration $(C)$, length of fumigation time $(T)$ (e.g., the $C \times T$ index) (14), and the physiological state of the organisms to be controlled.

Field studies conducted in the United States and other countries have tested metam-Na as a stand-alone treatment or by sequential application following halogenated fumigants in strawberry, vegetable, and floricultural crops as an alternative to methyl bromide for efficacy of control of a variety of soilborne pests $(3,10,12$, 
$13,16,17,21,30,39)$. Studies on floricultural crops in California showed that metam- $\mathrm{Na}$ at $200 \mathrm{~kg}$ a.i. $\mathrm{ha}^{-1}$ significantly reduced Liatris stem rot incidence caused by Sclerotinia sclerotiorum (16) and survival of Pythium spp. and Fusarium oxysporum in Calla lily (Zantedeschia sp.) production systems (17). The same authors found that metam-Na provided inadequate control of Phytophthora spp., seeds of little mallow (Malva parviflora), tubers of yellow nutsedge (Cyperus esculentus), and Calla lily volunteers. Duniway (12) and Guo et al. (21) showed that metam-Na applied alone at about 280 liters ha ${ }^{-1}$ (about $97 \mathrm{~kg}$ a.i. ha ${ }^{-1}$ ) did not provide sufficient control of Verticillium dahliae and Fusarium spp. in California strawberry. However, sequential application of metam-Na at $120 \mathrm{~kg}$ a.i. ha ${ }^{-1}$ about 5 to 7 days after the application of halogenated fumigants such as chloropicrin (Pic) or InLine (emulsified formulation of 1,3-dichloropropene plus chloropicrin) significantly improved the efficacy against soilborne pathogens and weeds relative to single fumigant applications $(3,12,30)$.

The efficacy of pesticide fumigants for controlling soilborne pests and diseases in various crops depends on the nature of the key pest complex in different cropping systems as well as crop-specific pest thresholds and the fumigant movement and distribution pattern in the soil. The latter is controlled by physical and chemical properties of the fumigants. Compared to methyl bromide, metam-Na has a lower water solubility, vapor pressure, and Henry's constant $\left(\mathrm{K}_{\mathrm{H}}\right.$, air/water ratio), which results in reduced movement and distribution in the soil gaseous phase (2). Moreover, air quality is of increasing concern for the San Joaquin Valley, Ventura County, and Southeast Desert areas of California. Fumigants have been identified among the top 10 sources for volatile organic compounds (VOCs) that contribute to smog in these areas, and stringent regulations will be enforced in 2008 to reduce fumigant emissions (California DPR, 2004 at http://www.cdpr.ca.gov/docs/pur/vocproj/ vocmenu.htm). Therefore, lower rates of fumigant use in agricultural production are also critical in efforts to improve air quality. Logistic dose-response models were developed for a 1,3-dichloropropene and chloropicrin combination based on lethal concentrations necessary for control of 50 and $90 \%$ of the tested weed seeds and pathogen populations ( $\mathrm{LC}_{50}$ and $\mathrm{LC}_{90}$, respectively) (29). However, $\mathrm{LC}_{50}$ and $\mathrm{LC}_{90}$ values for the control of major soilborne fungi and oomycetes, nematodes, and weeds under controlled conditions are unknown for other alternative fumigants, including metam-Na.

The objectives of this study were to (i) develop logistic dose-response models for metam-Na applied to a sandy loam soil under controlled conditions for important weed, soilborne fungi and oomycete pathogens, and parasitic nematodes, and (ii) to determine $\mathrm{LC}_{50}$ and $\mathrm{LC}_{90}$ for metam$\mathrm{Na}$ and these key pests in a sandy loam soil at 10 and $20^{\circ} \mathrm{C}$. This temperature range is within that expected in the field during soil fumigation in California's coastal areas and inland valleys (i.e., San Joaquin Valley).

\section{MATERIALS AND METHODS}

Soil. Soil samples were collected from the top $15 \mathrm{~cm}$ from the California Strawberry Commission Research facilities near Watsonville $\left(121^{\circ} 50^{\prime} \mathrm{W}, 36^{\circ} 54^{\prime} \mathrm{N}\right)$, CA, in a plot without a known history of fumigation. The soil was classified as an Elder sandy loam (coarse-loamy, mixed, thermic, Cumulic Haploxeroll), with a mean particle size distribution of $62 \%$ sand, $26 \%$ silt, and $12 \%$ clay. The $\mathrm{pH}$ was $7.75\left(\mathrm{H}_{2} \mathrm{O}\right)$ and $7.08\left(0.01 \mathrm{M} \mathrm{CaCl}_{2}\right)$, and the organic $\mathrm{C}$ content was $6 \mathrm{~g} \mathrm{~kg}^{-1}$ soil. This sandy loam soil was selected because it is a typical soil on which much of the strawberry and cut flower production occurs in California. Moist field soil was passed through a 2$\mathrm{mm}$ sieve prior to use.

Pathogen, nematode, and weed inoculum preparation. Soil naturally infested with Pythium ultimum (50 to 100 propagules per gram of soil) and Verticillium dahliae (30 to 45 microsclerotia per gram of soil) was obtained from a lettuce field in Santa Cruz County, CA (inoculum densities determined as indicated below). To ensure that population densities of $P$. ultimum were sufficient to evaluate fumigant efficacy, soils were amended with pathogen inoculum produced in the laboratory (34). Briefly, $500 \mathrm{~g}$ of air-dried soil was amended with dried, crushed sugar

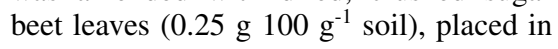
a small plastic autoclave bag, stoppered with a foam plug, and autoclaved for 50 min. Sterile water was added to bring the soil to approximately $-10 \mathrm{kPa}$, and an agar culture of two isolates of the pathogen recovered from the same soil used in this experiment was added. After 7 days incubation at room temperature $\left(21^{\circ} \mathrm{C}\right)$ with occasional mixing, the soil was removed and dried under a laminar flow hood. The dried soil was mixed and propagule densities determined by dilution plating as described below, and it was subsequently used to infest the field soil.

Additional samples of soil were infested with inoculum of Phytophthora cactorum. Inoculum was produced as previously described in jars of V8 juice-oatvermiculite substrate (7). The pathogen was allowed to colonize the substrate for 1 month, during which time it formed mycelium and oospores. The infested substrate was poured into a wrap of cheesecloth and washed in tap water to leach away unassimilated nutrients. The washed inoculum was thoroughly mixed with the soil (1 part substrate/5 parts soil, vol/vol), which was divided into $30 \mathrm{~cm}^{3}$ samples, and each was wrapped snugly in a synthetic fabric pouch (i.e., a "sample bag") that was firmly tied with a nylon cord as previously described (29). The sample bags were placed in the microcosms as described below.

Soil naturally infested with the citrus nematode (Tylenchulus semipenetrans Cobb) was obtained from a citrus orchard in Glen County, CA. Small muslin bags (Hubco Soil Sample Bags, Forestry Suppliers, Inc., Jackson, MS) were filled with $50 \mathrm{~cm}^{3}$ of infested soil and firmly tied with a nylon cord. The sample bags were placed in the microcosms as described below.

Seeds of weeds common to strawberry production including Polygonum arenastrum (common knotweed), Stellaria media (common chickweed), Portulaca oleracea (common purslane), and Malva parviflora (little mallow), as well as tubers of Cyperus esculentus (yellow nutsedge) were selected for this study. S. media seeds were purchased (Herbiseed, New Farm, Mire Lane, West End, Twyford, RG10 ONJ, England). C. esculentus, M. parviflora, Portulaca oleracea, and Polygonum arenastrum seeds were obtained from Salinas Valley, CA, field weeds, and were transplanted and grown in a greenhouse or outdoor microplots (C. esculentus). Thirty seeds of each weed species were placed in one small mesh bag (Delnet Applied Extrusion Technologies, Inc., Middletown, DE). Weed seeds were prepared for germination assays as described by Haar et al. (22). Ten tubers of C. esculentus were placed in another mesh bag of the same size. Bags were heat sealed, trimmed to final dimensions of $5 \times 5 \mathrm{~cm}$, and stored for $\leq 5$ days at room temperature prior to the microcosm study.

Microcosm preparation and metam$\mathrm{Na}$ application. Infested soil was thoroughly mixed with field soil and placed in microcosms consisting of 230-ml jars containing $150 \mathrm{~g}$ soil (dry wt) and preconditioned at $20^{\circ} \mathrm{C}$ for $24 \mathrm{~h}$ prior to treatment. On the day of metam-Na application, two nylon mesh bags containing soil infested with Phytophthora cactorum and $T$. semipenetrans were buried in each microcosm at 3 and $5 \mathrm{~cm}$ depth, respectively. Two mesh bags, one containing seeds of Polygonum arenastrum, S. media, Portulaca oleracea, and M. parviflora, and another bag containing $C$. esculentus tubers were buried in microcosms at 1.0 and 1.5 $\mathrm{cm}$ soil depth, respectively. Weed seed bags were imbibed in moist field soil (near field capacity) at $20^{\circ} \mathrm{C}$ for $24 \mathrm{~h}$ prior to treatment. Imbibition was completed in under a day at room temperature $(23 \pm$ $2^{\circ} \mathrm{C}$ ) (5). Previous studies indicated that dry seeds of $S$. media and Portulaca oleracea were not sensitive to fumigation with chloropicrin, but seeds moistened with water were sensitive (22). Seeds of $M$. parviflora and Erodium cicutarium were not sensitive to fumigation with chloropicrin dry or wet. 
The treatment design consisted of 12 metam-Na concentrations and an untreated control at two temperatures in four randomized replicated microcosms per pest combination. The commercial formulation of metam-Na (Sectagon 42, 42.2\% a.i.; Tessenderlo Kerley, Inc., Phoenix, AZ) was applied to the soil to achieve final concentrations of $0,10,25,50,80,105$, $130,265,530,795,1,060,1,325$, and $2,650 \mu \mathrm{mol} \mathrm{kg} \mathrm{kg}^{-1}$ soil (dry wt) or field application rates ranging between 16 and $4,050 \mathrm{~kg}$ of the formulated fumigant per hectare (i.e., about 7 to $1,700 \mathrm{~kg}$ metam$\left.\mathrm{Na} \mathrm{ha}{ }^{-1}\right)$. Application rates were based on label application directions for this fumigant in the field (187 to 700 liters $\mathrm{ha}^{-1}$ or 180 to $360 \mathrm{~kg}$ a.i. $\mathrm{ha}^{-1}$ ) (15) represented in the present study by intermediate concentration rates. These rates are equivalent to MITC concentrations of $1,2,4,6,8,10$, 19, 39, 58, 77, 97, and $193 \mathrm{mg} \mathrm{kg}^{-1}$ soil, assuming that $100 \%$ of the applied metam$\mathrm{Na}$ is converted to MITC.

Metam-Na at different concentrations was applied to the soil surface in the microcosms by syringe as a freshly prepared aqueous solution to bring soil moisture content from $4 \%$ to an average of $15 \%$ (wt/wt). The control received water instead of metam-Na solution to adjust to the same soil moisture content. Additional microcosms were prepared for treatment with the 12 different metam-Na concentrations studied and water without pathogen, nematode, and weed seed mesh bags for measuring the generation and dissipation rates of MITC in the soil air-water interface. All microcosms were sealed with air-tight lids and then transferred into temperaturecontrolled plant growth chambers (Series 101; Percival Scientific, Boone, IA) for 24 $\mathrm{h}$ at 10 or $20^{\circ} \mathrm{C}$, with temperature variations less than $0.5^{\circ} \mathrm{C}$. Exposure time was selected based on studies with metam- $\mathrm{Na}$ under controlled conditions showing that the maximum MITC concentration in the headspace was recorded within 5 to $6 \mathrm{~h}$ after metam-Na application in soils with a wide range of physical and chemical properties (39).

MITC concentration in the soil airwater interface. At 2, 6, 19, and $24 \mathrm{~h}$ after metam-Na application, microcosms without inoculum or seed bags were removed from the growth chambers and immediately stored at $-20^{\circ} \mathrm{C}$ until analysis. Soil extraction was conducted following the method described by Ma et al. (33). Briefly, $10 \mathrm{~g}$ of treated soil were placed in 20 -ml glass vials while still frozen, and 5 $\mathrm{ml}$ of a $30 \% \mathrm{NaCl}$ solution and $5 \mathrm{ml}$ ethyl acetate/CS $\mathrm{CS}_{2}$ mixture $(80 \% / 20 \%)$ were added to each vial. The vials were immediately capped with gray Teflon coated butyl septa and aluminum seals. The vials were shaken for $30 \mathrm{~min}$ on a horizontal shaker (180 oscillations $\mathrm{min}^{-1}$ ), allowed to settle for $30 \mathrm{~min}$, and then $1 \mathrm{ml}$ of the solvent supernatant was pipette-transferred into a 2-ml amber glass GC vial and recapped. The supernatant was analyzed for MITC on a split/splitless Agilent (Wilmington, DE) 6890 gas chromatograph (GC) equipped with a Agilent 5973N mass selective detector (MS) and a Zebron ZB624 column $(30 \mathrm{~m} \times 0.25 \mathrm{~mm}$ diameter $\times$ $1.4 \mu \mathrm{m}$ film thickness) for volatile compound separation. The determined total GC flow rate was $56.7 \mathrm{ml} \mathrm{min}^{-1}$ using helium carrier gas. The injector temperature was $140^{\circ} \mathrm{C}$ and the oven temperature program was $45^{\circ} \mathrm{C}$ for $2 \mathrm{~min}$, then increased by $15^{\circ} \mathrm{C} \mathrm{min}{ }^{-1}$ to $140^{\circ} \mathrm{C}$ and held at this temperature for $0.5 \mathrm{~min}$. The extraction efficacy of MITC was calculated as the percentage of MITC recovered relative to the maximum theoretical MITC amount produced from the applied dose of metam-Na to each microcosm. This value was calculated using the number of moles of metam$\mathrm{Na}$ applied to the soil, and assuming a stoichiometric conversion of metam-Na to MITC. The mean extraction efficacy was $95( \pm 4) \%$.

Soil sampling and retrieval of mesh bags and sample bags. After $24 \mathrm{~h}$ of fumigation, microcosms were vented under a laminar flow hood for $5 \mathrm{~min}$. Then soils were mixed and vented again for another $30 \mathrm{~min}$ to release any remaining volatile fumigant. Preliminary studies showed that $>95 \%$ of metam sodium in microcosms dissipated within $30 \mathrm{~min}$ after opening the microcosms in a high speed laminar hood. Nylon bags containing Phytophthora cactorum, T. semipenetrans, weed seeds, and tubers were retrieved, and soil samples were taken for analysis of survival of $V$. dahliae and Pythium ultimum within $2 \mathrm{~h}$ after venting the microcosms.

Weed seed viability. Seeds were removed from mesh bags, sorted by species, and tested for viability colorimetrically with tetrazolium chloride (TTC) (20). The seeds were allowed to imbibe on filter paper (Whatman no. 1) moistened with 1 $\mathrm{ml}$ of sterile deionized water in plastic petri dishes $(100 \mathrm{~mm}$ diameter, $15 \mathrm{~mm}$ high). Petri dishes were sealed with paraffin film and placed in a germination chamber at $21^{\circ} \mathrm{C}$ in darkness for 20 to $24 \mathrm{~h}$. Imbibed seeds were cut with a scalpel and placed in another petri dish, cut side down, on filter paper moistened with $1 \mathrm{ml}$ of a $0.1 \%$ (wt/vol) 2,3,5-tetrazolium chloride solution. Petri dishes were sealed with paraffin film and returned to the germination chamber for another 20 to $24 \mathrm{~h}$, and then evaluated under a microscope for staining of the embryo. Tubers of C. esculentus were sprouted in petri dishes in a germination chamber at a day/night temperature cycle of $20 / 10^{\circ} \mathrm{C}\left(10^{\circ} \mathrm{C}\right.$ fumigation temperature) and $35 / 20^{\circ} \mathrm{C}\left(20^{\circ} \mathrm{C}\right.$ fumigation temperature). Seed or tuber viability was calculated as the percentage of viable seeds or tubers after fumigant treatment relative to seed or tuber viability at time zero of the experiment.
Survival of $\boldsymbol{V}$. dahliae. Soils were airdried in the laboratory $\left(23 \pm 2^{\circ} \mathrm{C}\right)$, mixed thoroughly, and pulverized using mortar and pestle. From each sample, $10 \mathrm{~g}$ of soil was placed in snap cap vials and mixed with $2.5 \mathrm{ml}$ of a $d l$-methionine solution $\left(7.5 \mathrm{mg} \mathrm{ml}^{-1}\right)$ (28). Vials were capped and incubated in the dark at $30^{\circ} \mathrm{C}$ for 1 week. The vials were then opened and allowed to air-dry for 1 week at 22 to $24^{\circ} \mathrm{C}$. Samples were repulverized and dispensed onto petri dishes containing modified NP-10 selective medium (27) using the modified Anderson sampler (9). With the Anderson sampler, $0.5 \mathrm{~g}$ of pulverized soil from each sample was distributed over two replicates of six petri dishes. Plates were incubated in the dark at 22 to $24^{\circ} \mathrm{C}$ for 3 weeks. After incubation, the surface of the agar media was gently washed under running tap water to dislodge and remove soil particles. Washed petri dishes were examined for $V$. dahliae microsclerotia clusters under a dissecting microscope with transmitted light. Counts from the two subsamples per experimental unit, where each unit was replicated four times, were combined for mean values and expressed as microsclerotia per gram of dry soil.

Survival of Pythium ultimum. One gram of air-dried soil was added to $10-\mathrm{ml}$ sterilized water blanks (triplicate tubes for each sample), vortexed to mix the soil, and $500 \mu \mathrm{l}$ were distributed evenly over five petri dishes containing a semi-selective Pythium medium (34). The medium consisted of corn meal agar (17 $\mathrm{g} \mathrm{liter}^{-1}, \mathrm{BBL}$, Kansas City, MO) amended immediately after autoclaving with $0.1 \%$ Tween 20 followed after cooling to $50^{\circ} \mathrm{C}$ by pimaricin $\left(10 \mathrm{mg} \mathrm{liter}^{-1}\right)$, penicillin $(100 \mathrm{mg}$ liter $\left.^{-1}\right)$, ampicillin $\left(250 \mathrm{mg} \mathrm{liter}^{-1}\right)$, rifampicin (10 $\left.\mathrm{mg} \mathrm{liter}^{-1}\right)$, rose bengal (50 mg liter $^{-1}$ ), and Benomyl 50WP (20 mg liter ${ }^{-1}$, DuPont, Wilmington, DE). After $24 \mathrm{~h}$ incubation at $25^{\circ} \mathrm{C}$, the surface of the plates was washed free of soil under a gentle stream of water and the number of colonies counted. Plates were placed back into the incubator and subsequent counts made again after $24 \mathrm{~h}$. The total colony counts were expressed as CFU g ${ }^{-1}$ dry soil, and the presented data reflect the mean of the three subsamples per experimental unit, where each unit was replicated four times.

Survival of Phytophthora cactorum. Soil samples infested with $P$. cactorum were assayed for pathogen survival by dilution plating. A subsample from each treatment was air-dried in an open petri dish placed in a fume hood overnight. For each dried subsample, $2 \mathrm{~g}$ of the soil was added to $10 \mathrm{ml}$ of sterile distilled water in a 20-ml test tube and vortexed for $1 \mathrm{~min}$. Immediately afterward, aliquots of $0.1 \mathrm{ml}$ of the soil suspension were spread evenly on a semi-selective medium (17 $\mathrm{g} \mathrm{liter}^{-1}$, BBL, Kansas City, MO), pimaricin (10 mg liter ${ }^{-1}$ ), ampicillin (250 mg liter $\left.{ }^{-1}\right)$, rifampicin (10 $\left.\mathrm{mg} \mathrm{liter}^{-1}\right)$, and pentachloronitro- 
benzene ( $25 \mathrm{mg} \mathrm{liter}^{-1}$ ) on each of two 100-mm-diameter petri dishes. The plates were incubated for 7 days at $18^{\circ} \mathrm{C}$. The debris on the surface of each plate was then cleaned under running tap water while gently rubbing the agar surface with a soft cheesecloth sponge. Colonies characteristic of $P$. cactorum were counted and then observed microscopically to confirm their identity. The colony counts were expressed as CFU $\mathrm{g}^{-1}$ dry soil on a whole-sample basis.

Survival of T. semipenetrans. Muslin bags containing $50 \mathrm{~cm}^{3}$ moist field soil infested with $T$. semipenetrans were analyzed for live nematodes after extraction by a modified Bearmann Funnel system (4). Samples were kept on funnels at room temperature for $72 \mathrm{~h}$. Juvenile nematodes were counted microscopically in a $10-\mathrm{ml}$ aliquot from each sample.

Data analysis. The experiment was arranged in a randomized split-plot design with the temperature (4 replicate chambers $\times 2$ temperatures) as the main plot and the

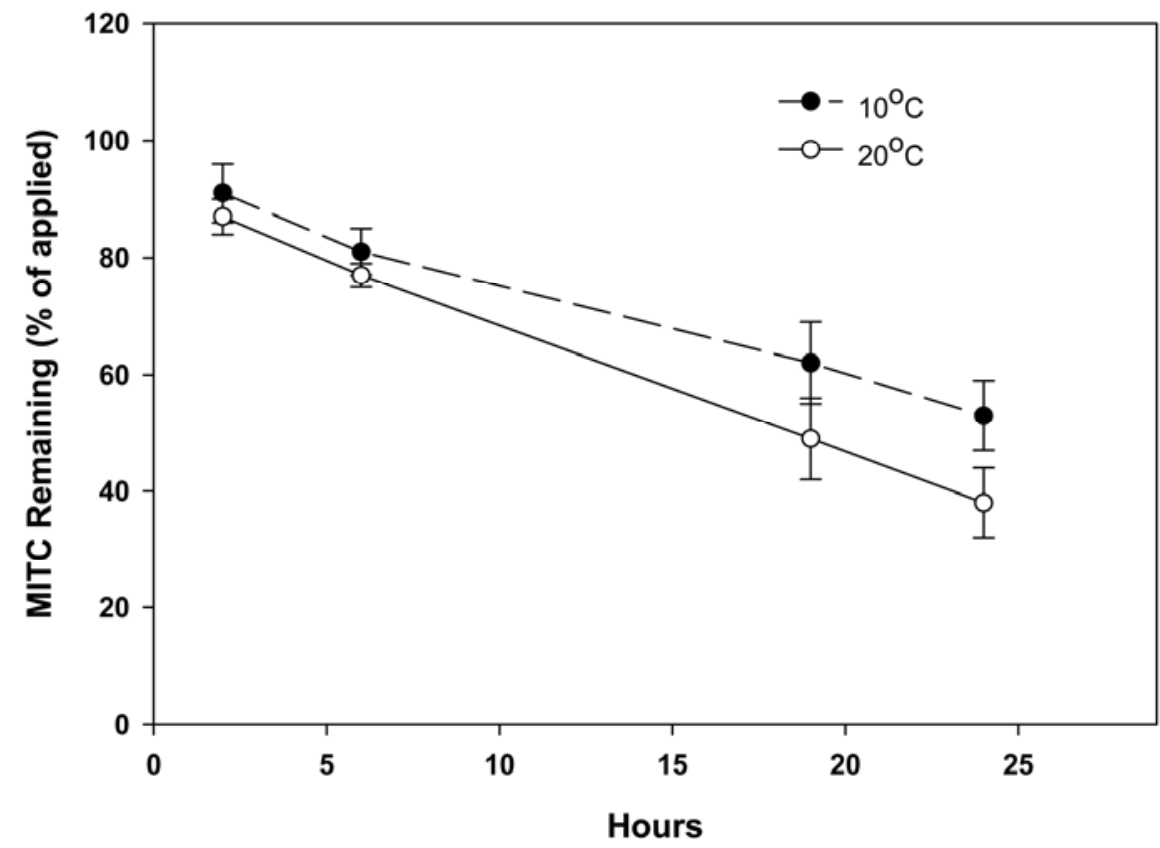

Fig. 1. Relative methyl isothiocyanate (MITC) concentration and standard errors of the mean in an Elder sandy loam $(\mathrm{pH} 7.1)$ over a 24-h time course incubated at 10 and $20^{\circ} \mathrm{C}$. Error bars represent the standard deviation, $n=8$.

fumigant concentration (12 fumigant concentrations, untreated controls, and microcosms without pathogen samples) as the subplot. Each treatment was replicated four times. The experiment was conducted in December 2004 and repeated in September 2005 (total of 2 trials [runs]). Multivariate analysis of variance (ANOVA) was used to assess the effects of temperature, fumigant concentration, and run on mortality of weed seeds, tubers, nematodes, and pathogens. Dose response relationships between metam-Na concentration and mortality of target pest species was computed using three nonlinear functions: negative exponential, hyperbolic saturation, and logistic (sigmoidal). Model fit was assessed using $R^{2}$ values and standard error estimates. The relationship between the percentage of weed seed, $C$. esculentus tuber, pathogen, and nematode mortality, and the logarithm of the metam$\mathrm{Na}$ concentration was generally best described by a logistic curve according to the sigmoidal logistic probability model:
Table 1. Probability levels of multivariate ANOVA for the effects of temperature (temp.), metam-Na concentration (conc.), trial (run), and the interactions among these factors on mortality of weed seeds, tubers, soilborne pathogens, and nematodes

\begin{tabular}{|c|c|c|c|c|c|c|c|c|c|c|}
\hline \multirow[b]{3}{*}{ Factors } & \multirow[b]{3}{*}{ Overall } & \multicolumn{9}{|c|}{ Species } \\
\hline & & \multicolumn{5}{|c|}{ Weeds } & \multicolumn{3}{|c|}{ Pathogens } & \multirow{2}{*}{$\begin{array}{c}\text { Nematodes } \\
\text { Tylenchulus } \\
\text { semipenetrans }\end{array}$} \\
\hline & & $\begin{array}{l}\text { Polygonum } \\
\text { arenastrum }\end{array}$ & $\begin{array}{c}\text { Stellaria } \\
\text { media }\end{array}$ & $\begin{array}{c}\text { Portulaca } \\
\text { oleracea }\end{array}$ & $\begin{array}{c}\text { Malva } \\
\text { parviflora }\end{array}$ & $\begin{array}{c}\text { Cyperus } \\
\text { esculentus }\end{array}$ & $\begin{array}{c}\text { Verticillium } \\
\text { dahliae }\end{array}$ & $\begin{array}{l}\text { Pythium } \\
\text { ultimum }\end{array}$ & $\begin{array}{c}\text { Phytophthora } \\
\text { cactorum }\end{array}$ & \\
\hline Temp. & $P<0.001$ & $P<0.001$ & $P<0.001$ & $P<0.001$ & n.s. ${ }^{\text {a }}$ & $P=0.050$ & n.s. & n.s. & n.s. & $P=0.014$ \\
\hline Conc. & $P<0.001$ & $P<0.001$ & $P<0.001$ & $P<0.001$ & n.s. & $P<0.001$ & $P<0.001$ & $P<0.001$ & $P<0.001$ & $P<0.001$ \\
\hline Run & n.s. & & & & & & & & & \\
\hline Temp. ${ }^{*}$ conc. & $P<0.001$ & $P<0.001$ & $P<0.001$ & $P<0.001$ & n.s. & $P<0.001$ & $P<0.001$ & $P<0.001$ & $P<0.001$ & $P<0.001$ \\
\hline Temp.*run & n.s. & & & & & & & & & \\
\hline Run*conc. & n.s. & & & & & & & & & \\
\hline Temp.*run*conc. & n.s. & & & & & & & & & \\
\hline
\end{tabular}

${ }^{a}$ n.s. = not significant.

$$
Y=\frac{a}{1+e-\left(\frac{x-x_{0}}{b}\right)}
$$

where $Y$ is the weed seed, tuber, nematode, or pathogen mortality (percent mortality relative to an untreated control) as a function of the logarithm of the metam-Na concentration $(x)$. Sigmoidal logistic probability models were computed using SigmaPlot 2001 (Systat Software Inc., Point Richmond, CA). Logistic dose-response curves were used to estimate the metam$\mathrm{Na}$ concentration required to achieve a weed seed and pathogen mortality of 50 $\left(\mathrm{LC}_{50}\right)$ or $90\left(\mathrm{LC}_{90}\right)$ percent using SAS probit procedure (SAS Institute Inc., Cary, NC). One-way ANOVA was used to assess effects of temperature (independent variable) on $\mathrm{LC}_{50}$ or $\mathrm{LC}_{90}$ (dependent variables), and when the $F$ test revealed an error probability of $\leq 5 \%$ ( $P \leq 0.05)$, the means were separated using the MannWhitney $U$ test with SPSS (version 12.07 for Windows, SPSS Inc., Chicago, IL).

\section{RESULTS}

Generation and dissipation of MITC in soils. On average, the actual MITC concentration in the soil relative to the maximum theoretical MITC was highest at $2 \mathrm{~h}$ after fumigant application and decreased steadily thereafter during the first $24 \mathrm{~h}$ of incubation, regardless of initial rate (Fig. 1). Actual MITC concentrations in this Elder sandy loam decreased from $\geq 91 \%$ of the applied MITC at $2 \mathrm{~h}$ after fumigant application to $\leq 53 \%$ after $24 \mathrm{~h}$ incubation at 10 and $20^{\circ} \mathrm{C}$. The decline in MITC concentration over the 24-h incubation period was more pronounced at $20^{\circ} \mathrm{C}$ than at $10^{\circ} \mathrm{C}$, although differences between temperatures were only significant at $24 \mathrm{~h}$ postfumigation. At $24 \mathrm{~h}$ after metam-Na application, the remaining MITC amount in the soil incubated at $10^{\circ} \mathrm{C}$ was $20 \%$ higher than that in soils incubated at $20^{\circ} \mathrm{C}$.

Viability of weed seeds, tubers, pathogens, and nematodes. Multivariate analysis of variance revealed that mortality of weed seeds, tubers, pathogens, and nematodes was affected by temperature, fumigant concentration, and the interaction between both factors $(P<0.001)$, but not 
by run effects (Table 1). Temperature*concentration effects were generally significant for all species studied $(P<$ 0.001 ), except for $M$. parviflora. Therefore, mortality of weed seed, tuber, pathogen, and nematode was presented pooled across trials (runs) but separated for temperature and species.

Weed seed and tuber viability. The effect of metam-Na concentrations relative to an untreated control soil on weed seed and tuber mortality varied among the weed species and incubation temperatures. Sigmoidal dose-response curves of weed seeds and tubers fumigated with different doses of metam-Na generally showed a strong relationship between increases in fumigant concentrations and mortality rates of $C$. esculentus tubers, and seeds of $S$. media, Polygonum arenastrum, and Portulaca oleracea with $R^{2} \geq 0.65$ (Figs. 2 and 3 ). These results also demonstrate that the sigmoidal probability model did not adequately describe the relationship between all metam-Na doses and mortality of C. esculentus if fumigated at $10^{\circ} \mathrm{C}$ (Fig. 3A). M. parviflora was the weed least affected by this fumigant (data not shown). On average, only $25 \%$ of the seeds of $M$. parviflora were killed during a 24-h exposure to the highest metam-Na concentra- tion $\left(2,650 \mu \mathrm{mol} \mathrm{kg} \mathrm{kg}^{-1}\right.$ soil) tested in this study.

The slope $b$ of the logistic curve of the nonlinear regression models indicated that the tolerance of weed seeds and tubers to soil fumigation with metam- $\mathrm{Na}$ at $10^{\circ} \mathrm{C}$ increased in the order Portulaca oleracea $=C$. esculentus $<$ Polygonum arenastrum $<$ $S$. media < M. parviflora, and at $20^{\circ} \mathrm{C}$ increased in the order Polygonum arenastrum $=C$. esculentus $=$ Portulaca ol eracea $<S$. media $<M$. parviflora (Tables 2 and 3). These results indicate that metam-Na was more active on weed seed and tubers at $20^{\circ} \mathrm{C}$ than at $10^{\circ} \mathrm{C}$. At $10^{\circ} \mathrm{C}$, the highest metam-Na concentration of $2,650 \mu \mathrm{mol} \mathrm{kg}{ }^{-1}$ tested here did not control $\geq 90 \%$ of $S$. media and M. parviflora seed and $C$. esculentus tubers, while at $20^{\circ} \mathrm{C}$ only $M$. parviflora seeds were not controlled by this concentration.

Probit analysis on logistic dose curves revealed that the concentration required to achieve $50 \%$ mortality (lethal concentration 50; $\mathrm{LC}_{50}$ ) of the seeds of Portulaca oleracea, Polygonum arenastrum, and $S$. media and $C$. esculentus tubers varied between 655 and 1,064 $\mu \mathrm{mol}$ metam-Na $\mathrm{kg}^{-1}$ soil, while concentrations of 1,242 to $\geq 2,650 \mu \mathrm{mol}$ metam-Na $\mathrm{kg}^{-1}$ soil were required to kill $90 \%$ (lethal concentration
90; $\left.\mathrm{LC}_{90}\right)$ of these seeds and tubers during a 24-h exposure at $10^{\circ} \mathrm{C}$ (Table 2). Metam$\mathrm{Na}$ concentrations of $\leq 2,650 \mu \mathrm{mol} \mathrm{kg}{ }^{-1}$ soil did not control seeds of $M$. parviflora during a 24-h exposure at 10 or $20^{\circ} \mathrm{C}$. At $20^{\circ} \mathrm{C}$, the minimum metam-Na concentration to control 50 and $90 \%$ of seeds of Portulaca oleracea, Polygonum arenastrum, and $S$. media and $C$. esculentus tubers ranged between 268 and $523 \mu \mathrm{mol}$ $\mathrm{kg}^{-1}$ soil, and between 717 and 2,008 $\mu \mathrm{mol}$ $\mathrm{kg}^{-1}$ soil, respectively.

Fungal and oomycete pathogen viability. Increasing concentrations of metam$\mathrm{Na}$ significantly increased mortality rates of $V$. dahliae, Pythium ultimum, and Phytophthora cactorum with $R^{2} \geq 0.79$ ( $P \leq$ $0.01)$ (Figs. 4 and 5). The sigmoidal probability model did not adequately describe the relationship between all metam- $\mathrm{Na}$ doses and mortality of Phytophthora cactorum if fumigated at $20^{\circ} \mathrm{C}$ (Fig. $5 \mathrm{~A}$ ). Among the soilborne pathogens evaluated, $P$. cactorum and $P$. ultimum were more sensitive to metam-Na fumigation than $V$. dahliae (Tables 2 and 3 ). In contrast to weed control, no improvement in fumigant efficacy was observed by increasing temperature from 10 to $20^{\circ} \mathrm{C}(P \geq 0.21)$. Metam-Na concentrations of $165 \mu \mathrm{mol} \mathrm{kg}{ }^{-1}$ controlled $90 \%$ of the populations of $P$. cactorum and
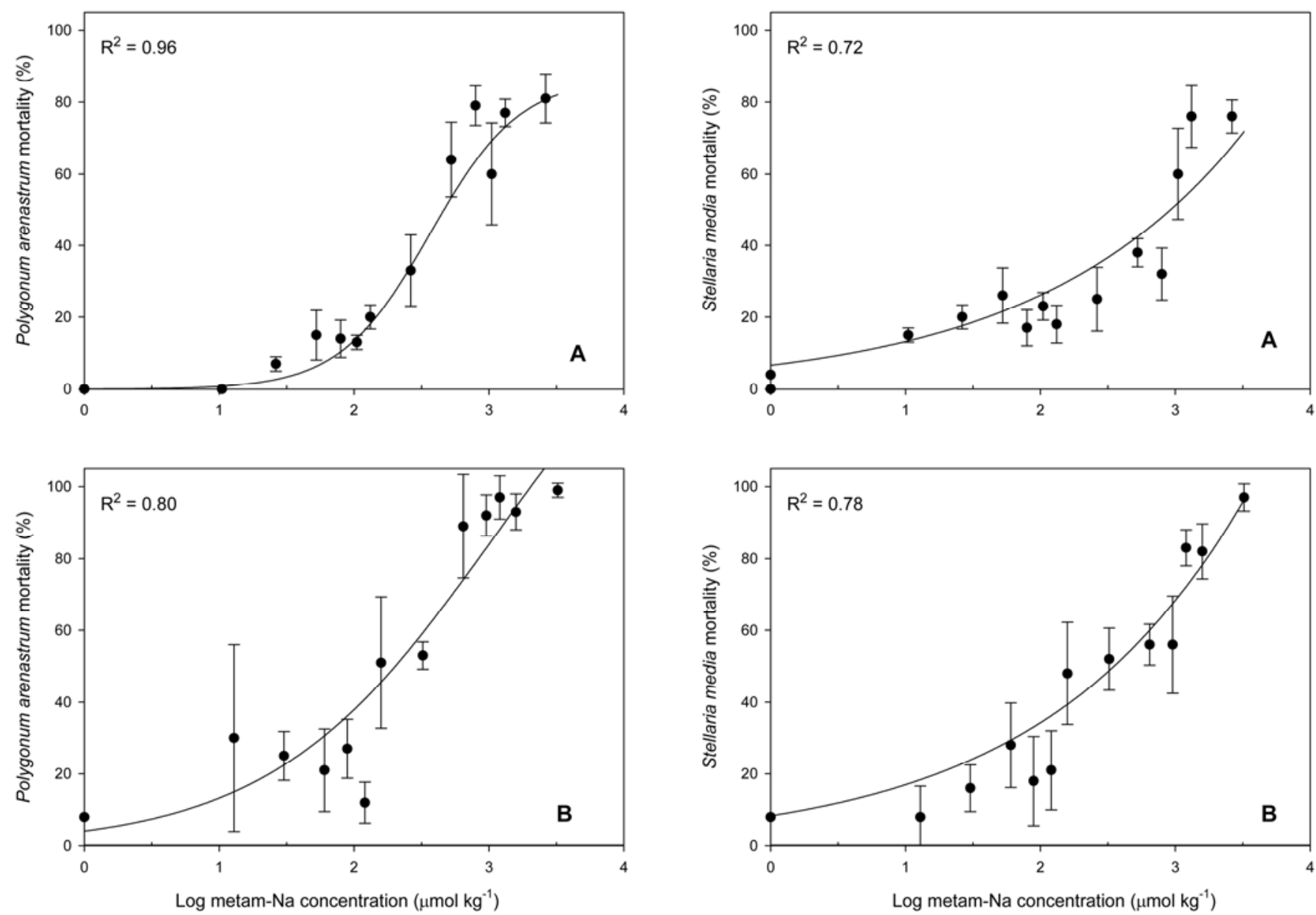

Fig. 2. Response of seeds of Polygonum arenastrum and Stellaria media to different metam-Na concentrations after fumigation of an Elder sandy loam soil for $24 \mathrm{~h}$ at $\mathbf{A}, 10^{\circ} \mathrm{C}$ and $\mathbf{B}, 20^{\circ} \mathrm{C}$. Error bars represent the standard deviation, $n=8$. 
P. ultimum, while a concentration of 737 $\mu \mathrm{mol} \mathrm{kg} \mathrm{kg}^{-1}$ metam-Na was required for an equivalent control of $V$. dahliae.

Probit analysis on logistic dose curves revealed that the minimum concentration required to kill $50 \%\left(\mathrm{LC}_{50}\right)$ of the pathogen samples ranged between 43 and 167 umol metam- $\mathrm{Na} \mathrm{kg}^{-1}$ soil for $P$. cactorum and $V$. dahliae, respectively, during $24 \mathrm{~h}$ exposure at $10^{\circ} \mathrm{C}$ (Table 2). Concentrations of 96 to $606 \mu \mathrm{mol}$ metam-Na kg-1 soil were required to kill $90 \%\left(\mathrm{LC}_{90}\right)$ of these pathogens. Metam-Na concentrations of $\leq 737$ $\mu \mathrm{mol} \mathrm{kg} \mathrm{kg}^{-1}$ soil were sufficient to control 90\% of the propagules of Phytophthora cactorum, Pythium ultimum, and V. dahliae at $20^{\circ} \mathrm{C}$ (Table 3 ).

Parasitic nematode viability. Mortality rates of $T$. semipenetrans increased with increasing metam-Na concentrations with
$R^{2} \geq 0.91$ ( $\left.P \leq 0.001\right)$ (Fig. 5). Sensitivity of $T$. semipenetrans toward fumigation with metam-Na was similar to that of the most sensitive soilborne pathogen (e.g., Phytophthora cactorum) evaluated in this study. Probit analysis on logistic dose curves revealed that the minimum concentration required to kill $50 \%\left(\mathrm{LC}_{50}\right)$ of the nematode samples ranged between 40 and $27 \mu$ mol metam-Na kg-1 soil during $24 \mathrm{~h}$
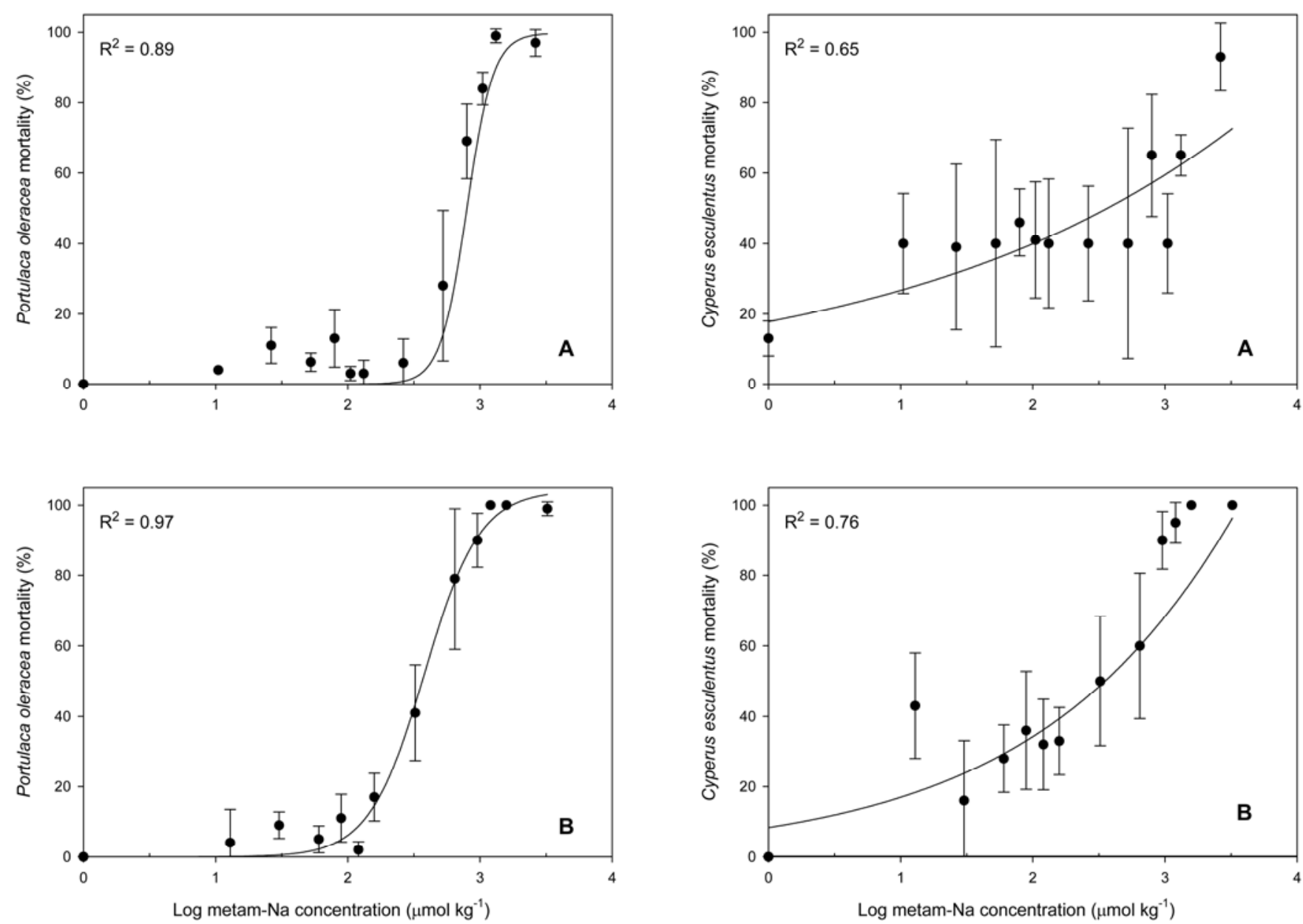

Fig. 3. Response of seeds of Portulaca oleracea and tubers of Cyperus esculentus to different metam-Na concentrations after fumigation of an Elder sandy loam soil for $24 \mathrm{~h}$ at $\mathbf{A}, 10^{\circ} \mathrm{C}$ and $\mathbf{B}, 20^{\circ} \mathrm{C}$. Error bars represent the standard deviation, $n=8$.

Table 2. Estimated parameters for nonlinear regression of weed seed, tuber, pathogen, and nematode mortality percentages on the concentration of metam$\mathrm{Na}\left(\mu \mathrm{mol} \mathrm{kg}{ }^{-1}\right.$ soil $)$ required to control $50\left(\mathrm{LC}_{50}\right)$ and $90\left(\mathrm{LC}_{90}\right)$ percent of the population at $10^{\circ} \mathrm{C}$ for $24 \mathrm{~h}$ exposure time

\begin{tabular}{|c|c|c|c|c|c|c|c|c|}
\hline \multirow[b]{2}{*}{ Species } & \multirow[b]{2}{*}{$b^{\mathbf{b}}$} & \multirow[b]{2}{*}{$R^{2}$} & \multicolumn{3}{|c|}{$\mathrm{LC}_{50} \mathrm{a}^{\mathrm{a}}$} & \multicolumn{3}{|c|}{$\mathrm{LC}_{90}{ }^{\mathrm{a}}$} \\
\hline & & & Lower limit $^{\mathrm{c}}$ & & Upper limit ${ }^{c}$ & Lower limit ${ }^{c}$ & & Upper limit $^{\mathrm{c}}$ \\
\hline \multicolumn{9}{|l|}{ Weeds } \\
\hline Polygonum arenastrum & 86.8 & 0.96 & 752 & 829 & 919 & 1,739 & 1,922 & 2,157 \\
\hline Stellaria media & 15.1 & 0.72 & 934 & 1,064 & 1,226 & 2,676 & $>2,650$ & \\
\hline Portulaca oleracea & 99.8 & 0.89 & 608 & 655 & 707 & 1,153 & 1,242 & 1,349 \\
\hline Malva parviflora & 6.4 & 0.32 & $\ldots$ & $>2,650$ & $\ldots$ & & $>2,650$ & $\ldots$ \\
\hline Cyperus esculentus & 16.9 & 0.65 & 481 & 667 & 895 & 2,308 & $>2,650$ & $\ldots$ \\
\hline \multicolumn{9}{|l|}{ Pathogens } \\
\hline Verticillium dahliae & 96.7 & 0.91 & 167 & 181 & 194 & 572 & 606 & 644 \\
\hline Pythium ultimum & 104.6 & 0.79 & 68 & 70 & 71 & 145 & 147 & 150 \\
\hline Phytophthora cactorum & 101.1 & 0.90 & 43 & 45 & 45 & 94 & 96 & 98 \\
\hline \multicolumn{9}{|l|}{ Nematodes } \\
\hline Tylenchulus semipenetrans & 103.9 & 0.91 & 40 & 41 & 42 & 97 & 98 & 100 \\
\hline
\end{tabular}

a $1.0 \mu \mathrm{mol} \mathrm{kg}{ }^{-1}$ soil is equivalent to $0.7 \mathrm{~kg} \mathrm{ha}^{-1}$ based on $30 \mathrm{~cm}$ soil depth.

${ }^{\mathrm{b}}$ Slope at the inflection point of the logistic curve indicating the susceptibility of the species to the fumigant $(P<0.01), n=8$.

c Confidence interval estimates $(P<0.05), n=8$. 
exposure at 10 and $20^{\circ} \mathrm{C}$, respectively (Tables 2 and 3). Concentrations of 98 to $69 \mu \mathrm{mol}$ metam-Na kg${ }^{-1}$ soil were required to kill $90 \%\left(\mathrm{LC}_{90}\right)$ of this nematode at 10 and $20^{\circ} \mathrm{C}$, respectively. Therefore, based on the $\mathrm{LC}_{50}$ and $\mathrm{LC}_{90}$ values, the efficacy of metam-Na for nematode control increased when the fumigation temperature was increased from 10 to $20^{\circ} \mathrm{C}$.

\section{DISCUSSION}

The efficacy of fumigant pesticides to control various soilborne pests depends on the concentration, the duration of exposure to the fumigant, and the characteristics and physiological state of the target pest organisms $(14,42)$. Soil moisture and temperature during fumigation affect generation, distribution, and degradation of fumigants as well as the physiological activity of fumigant-degrading microorganisms and target pest organisms (11,45). Previous studies showed that fumigant efficacy in sandy loam soils was highest at a moisture content of 14 to $15 \%$ (equivalent to about $-10 \mathrm{kPa}$ water potential) $(22,45)$. To clarify the influence of temperature on the efficacy of different metam-Na concentrations

Table 3. Estimated parameters for nonlinear regression of weed seed, tuber, pathogen and nematode mortality percentages on the concentration of metam$\mathrm{Na}\left(\mu \mathrm{mol} \mathrm{kg}{ }^{-1}\right.$ soil) required to control $50\left(\mathrm{LC}_{50}\right)$ and $90\left(\mathrm{LC}_{90}\right)$ percent of the population at $20^{\circ} \mathrm{C}$ for $24 \mathrm{~h}$ exposure time

\begin{tabular}{|c|c|c|c|c|c|c|c|c|}
\hline \multirow[b]{2}{*}{ Species } & \multirow[b]{2}{*}{$b^{\mathbf{b}}$} & \multirow[b]{2}{*}{$R^{2}$} & \multicolumn{3}{|c|}{$\mathbf{L C}_{50}{ }^{\mathrm{a}}$} & \multicolumn{3}{|c|}{$\mathrm{LC}_{90}{ }^{\mathrm{a}}$} \\
\hline & & & Lower limit $^{\mathrm{c}}$ & & Upper limit $^{\mathrm{c}}$ & Lower limit $^{\mathrm{c}}$ & & Upper limit $^{\mathbf{c}}$ \\
\hline \multicolumn{9}{|l|}{ Weeds } \\
\hline Polygonum arenastrum & 170.7 & 0.80 & 233 & 268 & 303 & 722 & 800 & 900 \\
\hline Stellaria media & 46.2 & 0.72 & 436 & 523 & 601 & 1,860 & 2,008 & 2,194 \\
\hline Portulaca oleracea & 104.2 & 0.97 & 349 & 380 & 414 & 661 & 717 & 786 \\
\hline Malva parviflora & 27.1 & 0.81 & & $>2,650$ & & & $>2,650$ & \\
\hline Cyperus esculentus & 146.2 & 0.76 & 258 & 313 & 376 & 732 & 848 & 1,019 \\
\hline \multicolumn{9}{|l|}{ Pathogens } \\
\hline Verticillium dahliae & 97.2 & 0.97 & 85 & 123 & 159 & 655 & 737 & 842 \\
\hline Pythium ultimum & 102.6 & 0.95 & 77 & 78 & 79 & 140 & 165 & 145 \\
\hline Phytophthora cactorum & 105.0 & 0.81 & 25 & 27 & 29 & 138 & 141 & 145 \\
\hline \multicolumn{9}{|l|}{ Nematodes } \\
\hline Tylenchulus semipenetrans & 101.1 & 0.99 & 27 & 28 & 28 & 68 & 69 & 70 \\
\hline
\end{tabular}

a $1.0 \mu \mathrm{mol} \mathrm{kg} \mathrm{kg}^{-1}$ soil is equivalent to $0.7 \mathrm{~kg} \mathrm{ha}^{-1}$ based on $30 \mathrm{~cm}$ soil depth.

${ }^{\mathrm{b}}$ Slope at the inflection point of the logistic curve indicating the susceptibility of the species to the fumigant $(P<0.01), n=8$.

${ }^{\mathrm{c}}$ Confidence interval estimates $(P<0.05), n=8$.
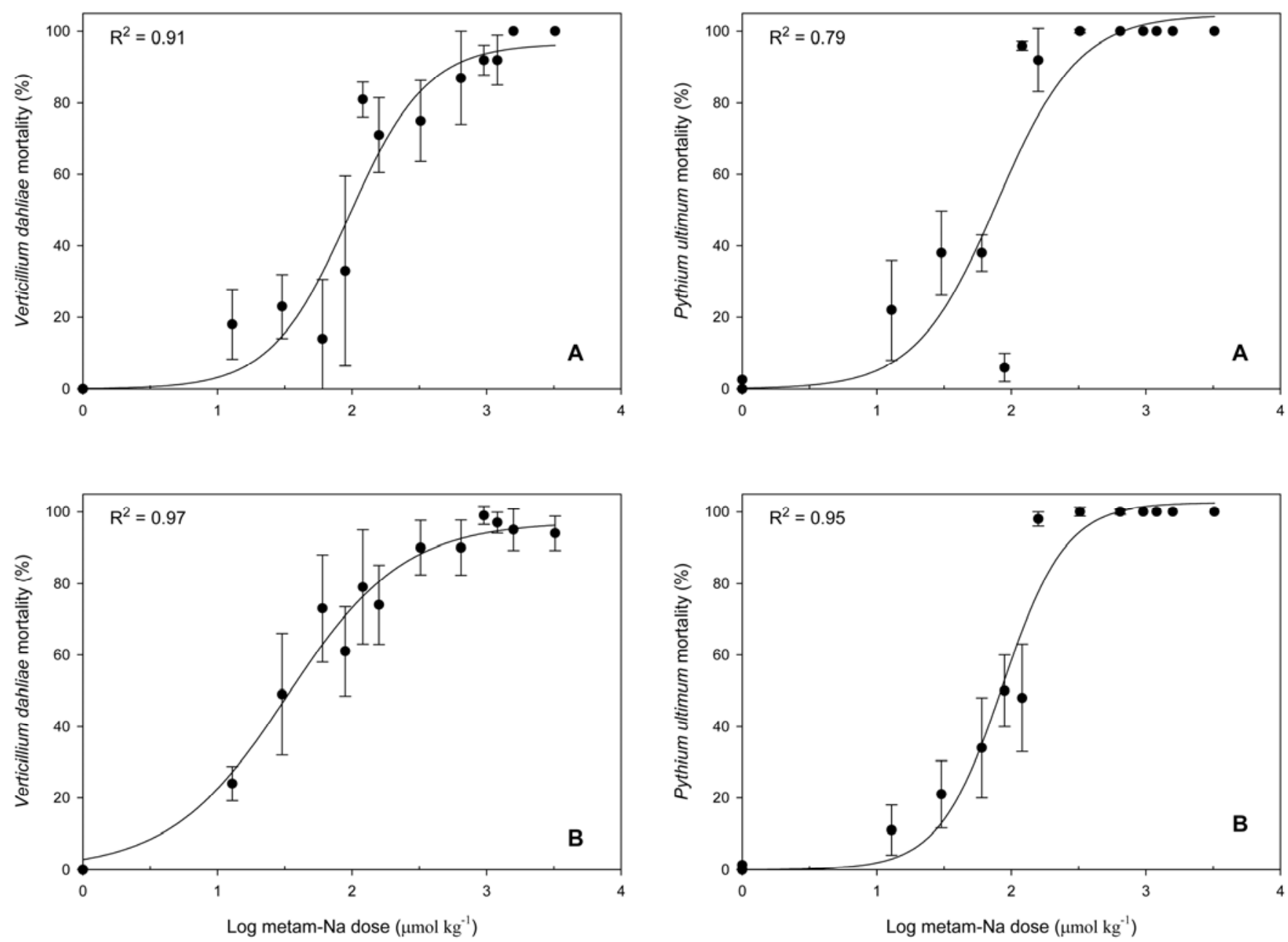

Fig. 4. Response of Verticillium dahliae and Pythium ultimum to different metam-Na concentrations after fumigation of an Elder sandy loam soil for $24 \mathrm{~h}$ at A, $10^{\circ} \mathrm{C}$ and $\mathbf{B}, 20^{\circ} \mathrm{C}$. Error bars represent the standard deviation, $n=8$. 
for controlling five major weeds, three soilborne plant pathogens, and one parasitic nematode in fumigated soil, a MITC generation and dissipation curve was developed. A logistic dose-response model provided a tool to estimate minimum effective metam-Na concentrations to control 50 or $90 \%$ of the population of different species of weeds, soilborne pathogens, and parasitic nematodes in fumigated Elder sandy loam soil with a water potential of $-10 \mathrm{kPa}$ at 10 and $20^{\circ} \mathrm{C}$. Logistic models did not adequately describe the relationship between all metam-Na doses and the mortality of $C$. esculentus and Phytophthora cactorum under all temperature conditions studied. Therefore, $\mathrm{LC}_{50}$ and $\mathrm{LC}_{90}$ values may not be valid for these two pest organisms. Moreover, doseresponse data were collected under controlled conditions, and the inoculum for some pathogens (i.e., P. cactorum) and weed seeds were not in the form or physiological status as would be found in field soil. These factors may have influenced the sensitivity of these organisms to fumigation relative to native populations in the soil. Also, an effect of spatial variations in soil temperature, texture, moisture, and age and location of individual weed seeds relative to the fumigant injection site cannot be excluded. Since soil texture, organic matter content, $\mathrm{pH}$, soil moisture, and temperature during fumigation, as well as fumigation history of the soil play a significant role in fumigant efficacy by controlling transport, conversion, and degradation of these pesticides in soil $(22,39,44,45)$, results would vary for different soils.

The maximum MITC concentration in this sandy loam soil fumigated under optimum moisture conditions was measured $2 \mathrm{~h}$ after metam-Na application for both temperatures, which was generally earlier than recently reported by others. TrikyDotan et al. (39) found that the maximum MITC concentration was recorded 5 to $6 \mathrm{~h}$ after metam-Na application for a range of soils with varying physical and chemical properties. A higher remaining MITC concentration after $24 \mathrm{~h}$ at $10^{\circ} \mathrm{C}$ than at $20^{\circ} \mathrm{C}$ (difference of $15 \%$ ) recorded in this study may be the result of slower degradation of MITC, as suggested by others $(15,32,36)$. Metam-Na can provide effective control of selected weed propagules (seeds and tubers) and of $V$. dahliae only at rates equivalent to or slightly higher than the maximum suggested label rates $(\geq 360 \mathrm{~kg}$ a.i. $\mathrm{ha}^{-1}$ ) for the commercial formulation of metam-Na (CDMS, 2007 at http://www. cdms.net/LabelsMsds/LMDefault.aspx?t=), while soilborne oomycete pathogens and parasitic nematodes were effectively controlled at significantly lower rates (about $68 \mathrm{~kg}$ a.i. $\mathrm{ha}^{-1}$ ). Therefore, the efficacy of field fumigation with the maximum metam-Na label rate will depend to a large extent upon the spectrum and distribution of potential pests and diseases in these fields. Among the weed species, seeds of Portulaca oleracea and Polygonum arenastrum were more sensitive to metam-Na than seeds of $S$. media and $M$. parviflora and tubers of C. esculentus. Metam-Na did not provide adequate control of the later weeds at $10^{\circ} \mathrm{C}$ under the concentration range and exposure time tested in this study. Increasing fumigation temperature to $20^{\circ} \mathrm{C}$ improved efficacy of control of most weeds. Improved fumigant efficacy at $20^{\circ} \mathrm{C}$ could be related to faster release of MITC in soil as shown elsewhere $(15,32,36,41)$, as well as to higher metabolic activity of weed seeds.

Effective metam-Na concentrations to kill $50 \%$ of C. esculentus were reported to be $6.5 \mu \mathrm{mol} \mathrm{\textrm {kg } ^ { - 1 }}$ soil (33). This $\mathrm{LC}_{50}$ value was about 50 times lower than the value estimated in the present study. The differences in $\mathrm{LC}_{50}$ values between these two studies may be related to differences in soil properties and/or exposure time to the
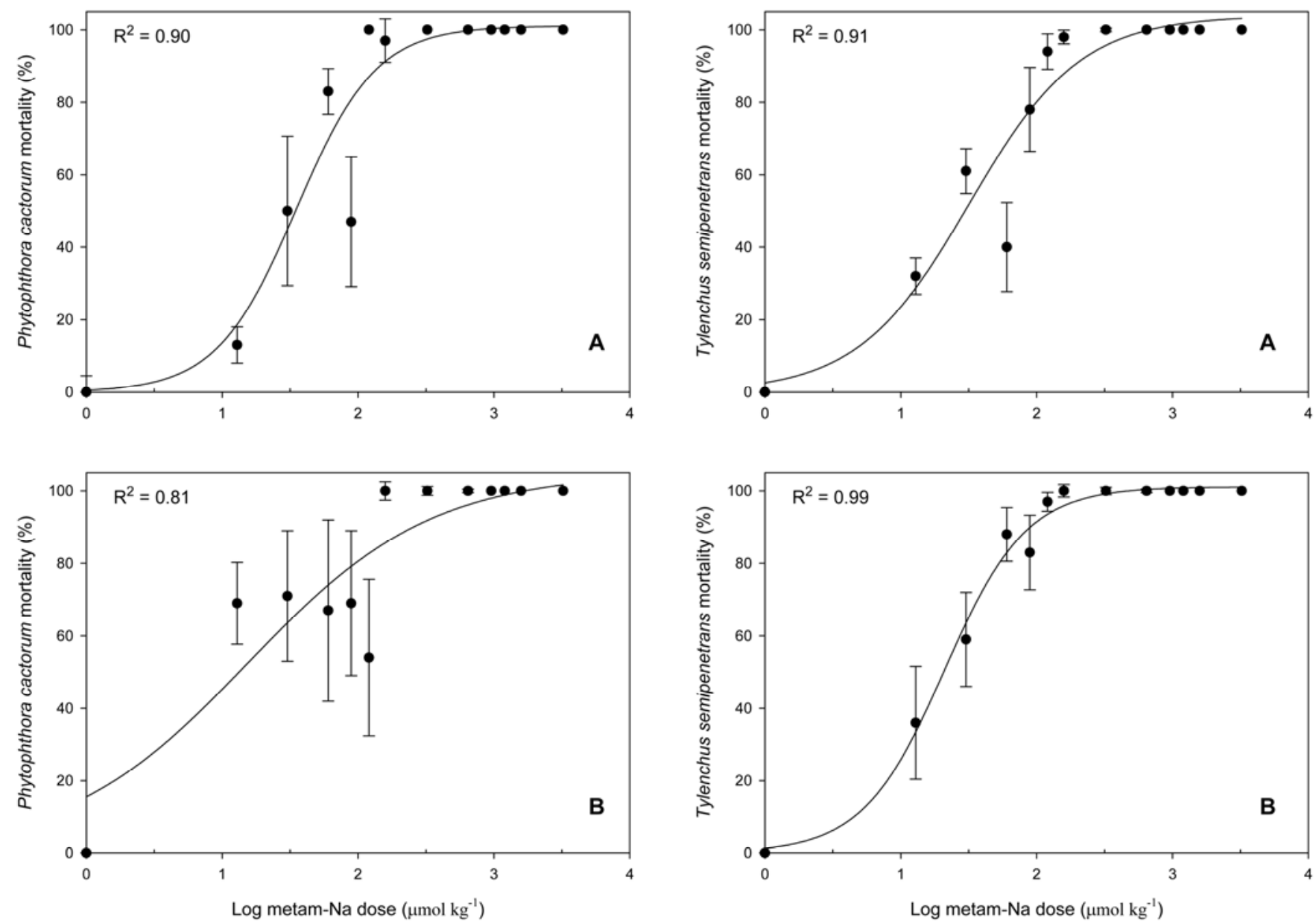

Fig. 5. Response of Phytophthora cactorum and Tylenchulus semipenetrans to different metam-Na concentrations after fumigation of an Elder sandy loam soil for $24 \mathrm{~h}$ at $\mathbf{A}, 10^{\circ} \mathrm{C}$ and $\mathbf{B}, 20^{\circ} \mathrm{C}$. Error bars represent the standard deviation, $n=8$. 
fumigant. Studies have shown that extending a pest's exposure to a fumigant enables dose reduction without affecting pest control efficacy (35).

M. parviflora and E. cicutarium seeds have been shown to be resistant to soil fumigation with metam-Na in the field $(13,22)$. Relative potency of metam-Na to control Portulaca oleracea at $20^{\circ} \mathrm{C}$ was 3.8 and 2.5 times lower than those of chloropicrin and InLine, respectively. Corresponding ratios for control of S. media were 3.5 and 1.2. In contrast, metam-Na had a 3.7 and 1.3 times higher relative potency for control of Polygonum arenastrum than chloropicrin and InLine, respectively. This difference in sensitivity may reflect differences in seed coat permeability to various fumigants. M. parviflora is relatively insensitive to all currently known fumigants, while $P$. arenastrum is moderately insensitive to chloropicrin (13). Greater sensitivity of the latter weed to metam-Na may reflect higher permeability of the seed coat to metam-Na than to chloropicrin. However, further research is required to verify the differential permeability of $P$. arenastrum seed to various fumigants.

Besides these differences in the relative potency of each fumigant on a molar concentration basis, differences in the sensitivity of weed species to various fumigants may also be related to fumigation time and activity spectrum since soil type, soil moisture content, and temperature during fumigation were similar in the laboratory studies with chloropicrin, InLine, and metam-Na. Other factors that play a role in controlling seed sensitivity toward fumigants are seed coat hardiness and impermeability (i.e., physical dormancy) to moisture and fumigants. M. parviflora and E. cicutarium belong to plant families with physical dormancy and hard seed coats (5), and fumigant penetration through hard seed coats is difficult under field conditions. Therefore, combinations of preplant fumigants with postplant herbicides and the use of different plastic mulches are considered to be more reliable methods to control hard-coated weed seeds $(25,26)$.

The efficacy of metam-Na to control soilborne pathogens increased in the order V. dahliae < Pythium ultimum $\leq$ Phytophthora cactorum, and soil temperature during fumigation did not affect efficacy of metam-Na against these pathogens in the temperature range tested $\left(10\right.$ and $\left.20^{\circ} \mathrm{C}\right)$ at $15 \%$ soil moisture content. Conflicting results were reported on the influence of soil temperature on the efficacy of metam$\mathrm{Na}$ against soilborne pathogens. The toxicity of MITC to Verticillium spp., Sclerotium rolfsii Sacc., Sclerotinia sclerotiorum, and Fusarium oxysporum increased with increasing soil temperature (6). Others reported that MITC has greater fungicidal efficacy at low temperatures (41) or under wet/cold soil conditions (37).
Phytophthora cactorum and Pythium ultimum showed similar sensitivity to the fumigant, which could in part be due to similarities in the resting structures they produce. Both pathogens survive in the soil as thick-walled oospores, and P. ultimum additionally survives as a thin-walled hyphal swelling. A dose-response study on the efficacy of soil fumigation with MB and methyl iodide against a range of soilborne pathogens including $F$. oxysporum, Phytophthora spp., Pythium ultimum, and $V$. dahliae revealed that $P$. ultimum and Phytophthora spp. were the most sensitive pathogens and $V$. dahliae was among the least sensitive species (24). However, these results may not reflect what is encountered in the field as the pathogen inoculum in these studies was produced on colonized seeds for 7 days prior to treatment, and hence the pathogens were in a mycelia stage (and likely more sensitive to the fumigant) than the pathogen resting structures formed in decaying plant matter as would be found in field soil. Using natural inoculum of $V$. dahliae, F. oxysporum, and Pythium ultimum, and culture produced oospores of Phytophthora cactorum, the $\mathrm{EC}_{50}$ values for InLine were 625, 306, 30, and $412 \mu \mathrm{mol} \mathrm{kg} \mathrm{kg}^{-1}$ soil, respectively (29). Compared with InLine, the relative potency of metam-Na was 5.1 times higher for control of $V$. dahliae, 2.6 times lower for control of Pythium ultimum, and 15.3 times higher for control of Phytophthora cactorum.

$T$. semipenetrans was one of the most sensitive organisms tested in this study, indicating that metam-Na has a high nematicidal activity. Minimum rates of 70 $\mu$ mol metam-Na kg${ }^{-1}$ soil (or $28 \mathrm{~kg}$ a.i. ha ${ }^{-1}$ ) were efficient in controlling $\geq 90 \%$ nematode growth at $20^{\circ} \mathrm{C}$. Nematode control efficacy of metam-Na was about $30 \%$ lower if fumigation occurred at $10^{\circ} \mathrm{C}$. Because the microcosms used in this study allow pathogens and nematodes to be exposed to constant soil type, soil moisture, and temperature conditions, pathogen and nematode control was a function of fumigant concentration and exposure time. Other factors that affect fumigant efficacy include the specific physiology of the target organism and the nature of long-term survival structures in soil, like for fungal and oomycete pathogens. Some of the factors responsible for the general resilience of $V$. dahliae propagules to soil fumigation include the aggregated cell mass that comprises microsclerotia and the melanized nature of microsclerotia. Melanin is known to protect fungi and other microorganisms from various abiotic and biotic stresses (8), and it can be hypothesized that it renders the microsclerotia resistant to certain thresholds of soil fumigants.

The results of this study revealed that metam-Na at a concentration of $850 \mu \mathrm{mol}$ $\mathrm{kg}^{-1}$ soil (equivalent to about $545 \mathrm{~kg}$
metam-Na ha ${ }^{-1}$, or $1,300 \mathrm{~kg}$ Sectagon 42 $\mathrm{ha}^{-1}$ ) over $24 \mathrm{~h}$ was sufficient to kill $\geq 90 \%$ of major weed seeds and propagules of soilborne pathogens and nematodes, with exception of $M$. parviflora and S. media. This rate is above the maximum label rate of $360 \mathrm{~kg}$ metam-Na ha-1, suggesting that appropriate combinations of different fumigants, fumigant/herbicides, fumigant/ plastic mulch, or fumigant/solarization should be used to improve the efficacy of control of this fumigant in field situations involving a multi-pest complex. The efficacy of metam-Na to control nematodes and weed propagules was improved by 30 and $60 \%$, respectively, if the temperature at the time of fumigation was increased from 10 to $20^{\circ} \mathrm{C}$, while degradation of MITC was increased by about $15 \%$. These results suggest higher fumigant resilience and thus phytotoxicity risk, as well as lower fumigant efficacy in low temperature areas or deeper soil layers.

\section{ACKNOWLEDGMENTS}

This work was supported, in part, by the USDACSREES agreement No. 05-51102-02381 and by grants from Tessenderlo Kerley Inc., Phoenix, AZ.

\section{LITERATURE CITED}

1. Aislabie, J., and Lloyd-Jones, G. 1995. A review of bacterial degradation of pesticides. Aust. J. Soil Res. 33:925-942.

2. Ajwa, H. A., Klose, S., Nelson, S. D., Minuto, A., Gullino, M. L., Lamberti, F., and LopezAranda, J. M. 2003. Alternatives to methyl bromide in strawberry production in the United States of America and the Mediterranean region. Phytopathol. Mediterr. 42:220-244.

3. Ajwa, H. A., Klose, S., Shem-Tov, S., Elmore, C., and Mellano, M. A. 2006. Ranunculus production with methyl bromide alternatives. In: Annu. Int. Res. Conf. Methyl Bromide Alternatives Emissions Reductions. (Proc. 36).

4. Ayoub, S. M. 1977. Plant nematology: An agricultural training aid. State of California, Department of Food and Agriculture, Division of Plant Industry, Sacramento, CA.

5. Baskin, C., and Baskin, J. M. 2001. Seeds. Ecology, Biogeography, and Evolution of Dormancy and Germination. Academic Press, San Diego, CA. pp. 101-132.

6. Ben-Yephet, Y., and Frank, Z. R. 1985. Effect of soil structure on penetration by metham sodium and of temperature on concentrations required to kill soilborne pathogens. Phytopathology 75:403-406.

7. Bhat, R. G., Colowit, P. M., Tai, T. H., Aradhya, M. K., and Browne, G. T. 2006. Genetic and pathogenic variation in Phytophthora cactorum affecting fruit and nut crops in California. Plant Dis. 90:161-169.

8. Butler, M. J., and Day, A. W. 1998. Fungal melanins: A review. Can. J. Microbiol. 44:1115-1136.

9. Butterfield, E. J., and DeVay, J. E. 1977. Reassessment of soil assays for Verticillium dahliae. Phytopathology 67:1073-1078.

10. Di Primo, P., Gamliel, A., Austerweil, M., Steiner, B., Beniches, M., Perez-Alon, I., and Katan, J. 2003. Accelerated degradation of metam-sodium and dazomet in soil: Characterization and consequences for pathogen control. Crop Prot. 22:635-646.

11. Dungan, R. S., Gan, J., and Yates, S. R. 2003 Accelerated degradation of methyl isothiocyanate in soil. Water Air Soil Pollut. 142:299310.

12. Duniway, J. M. 2002. Status of chemical alter- 
natives to methyl bromide for pre-plant fumigation of soil. Phytopathology 92:1337-1343.

13. Fennimore, S. A., Haar, M. J., and Ajwa, H. A. 2003. Weed control in strawberry provided by shank- and drip-applied methyl bromide alternative fumigants. HortScience 38:55-61.

14. Gamliel, A., Grinstein, A., Peretz, Y., Klein, L., Nachmias, A., Tsror, L., Livescu, L., and Katan, J. 1997. Reduced dosage of methyl bromide for controlling Verticillium wilt of potato in experimental and commercial plots. Plant Dis. 81:469-474.

15. Gan, J., Papiernik, S. K., Yates, S. R., and Jury, W. A. 1999. Temperature and moisture effects of fumigant degradation in soil. J. Environ. Qual. 28:1436-1441.

16. Gerik, J.S. 2005. Evaluation of soil fumigants applied by drip irrigation for Liatris production. Plant Dis. 89:883-887.

17. Gerik, J. S., Greene, I. D. Beckman, P., and Elmore, C. L. 2006. Preplant drip-applied fumigation for Calla lily rhizome nursery. Hort Technology 16:297-300.

18. Gerstl, Z., Mingelgrin, U., and Yaron, B., 1977. Behavior of Vapam and methylisothiocyanate in soils. Soil Sci. Soc. Am. J. 41:545-548.

19. Goodhue, R. E., Fennimore, S. A., and Ajwa, H. A. 2005. The economic importance of methyl bromide: Does the California strawberry industry qualify for a critical use exemption from the methyl bromide ban? Rev. Agric. Econ. 27:198-211.

20. Grabe, D. F., ed. 1970. Tetrazolium Testing Handbook. Contribution No. 29 to the Handbook on Seed Testing. Association of Official Seed Analysts, Las Cruces, NM. p. 62.

21. Guo, M., Yates, S. R., Papiernik, S. K., and Zheng, W. 2005. Incompatibility of metamsodium with halogenated fumigants. Pest Manag. Sci. 61:467-476.

22. Haar, M. J., Fennimore, S. A., Ajwa, H. A., and Winterbottom, C. Q. 2003. Chloropicrin effect on weed seed viability. Crop Prot. 22:109-115.

23. Himelrick, D. G., and Dozier, W. A., Jr. 1991. Soil fumigation and soil solarization in strawberry production. Adv. Strawberry Prod. 10:12-28.

24. Hutchinson, C. M., McGiffen, M. E., Ohr, H. D., Sims, J. J., and Becker, J. O. 2000. Efficacy of methyl iodide and synergy with chloropicrin for control of fungi. Pest Manag. Sci. 56:413418.

25. Hutchinson, C. M., McGiffen, M. E., Sims, J. J., and Becker, J. O. 2003. Fumigant combinations for Cyperus esculentum L. control. Pest Manag. Sci. 60:369-374

26. Johnson, M. S., and Fennimore, S. A. 2005. Weed and crop response to colored plastic mulches in strawberry production. HortScience 40:1371-1375.

27. Kabir, Z., Bhat, R. G., and Subbarao, K. V. 2004. Comparison of media for recovery of Verticillium dahliae from soil. Plant Dis. 88:49-55.

28. Kapulnik, E., Quick, J., and DeVay, J. E. 1985. Germination of propagules of Verticillium dahliae in soil treated with methionine and other substances affecting ethylene production. Phytopathology 75:1348.

29. Klose, S., Ajwa, H. A., Fennimore, S. A., Subbarao, K. V., Martin, F. N., and Browne, G. T. 2007. Dose response of weed seeds and soilborne pathogens to 1,3-D and chloropicrin. Crop Prot. 26:535-542.

30. Klose, S., Ajwa, H. A., Shem-Tov, S., Fennimore, S. A., Subbarao, K. V., MacDonald, J. D., Ferris, H., Martin, F. N., and Gerik, J. 2006. Methyl bromide alternatives for California-grown calla lilies. In: Annu. Int. Res. Conf. Methyl Bromide Alternatives Emissions Reductions. (Proc. 38).

31. Leistra, M., and Crum, S. J. H. 1990. Emission of methyl isothiocyanate to the air after application of metham-sodium to greenhouse soil. Water Air Soil Pollut. 50:109-121.

32. Leistra, M., and Smelt, J. H. 1974. Optimum soil conditions for fumigation with metham sodium. Agro-Ecosystems 1:169-176.

33. Ma, Q. L., Gan, J., Papiernik, S. K., Becker, J. O., and Yates, S. R. 2001. Degradation of soil fumigants as affected by initial concentration and temperature. J. Environ. Qual. 30:12781286

34. Martin, F. N. 1992. The genus Pythium. Pages 39-49 in: Methods for Research on Soilborne Phytopathogenic Fungi. L. L. Singleton, J. D. Mihail, and C. M. Rush, eds. American Phytopathological Society, St. Paul, MN.

35. Munnecke, D. E., and Van Gundy, S. D. 1979.
Movement of fumigant in soil, dosage response and differential effects. Annu. Rev. Phytopathol. 17:405-429.

36. Saeed, I. A. M., Rouse, D. I., and Harkin, J. M. 2000. Methyl isothiocyanate volatilization from fields treated with metam-sodium. Pest Manag. Sci. 56:813-817.

37. Saeed, I. A. M., Rouse, D. I., Harkin, J. M., and Smith, K. P. 1997. Effects of soil water content and soil temperature on efficacy of metham-sodium against Verticillium dahliae. Plant Dis. 81:773-776.

38. Smelt, J. H., and Leistra, M. 1974. Conversion of metam-sodium to methyl isothiocyanate and basic data on the behavior of MITC in soil Pestic. Sci. 5:401-407.

39. Triky-Dotan, S., Austerweil, M., Steiner, B. Peretz-Alon, Y., Katan, J., and Gamliel, A. 2007. Generation and dissipation of methyl isothiocyanate in soils following metam sodium fumigation: Impact on Verticillium control and potato yield. Plant Dis. 91:497-503.

40. Vallad, G. E., Bhat, R. G., Koike, S. T., Ryder, E. J., and Subbarao, K. V. 2005. Weedborne reservoirs and seed transmission of Verticillium dahliae in lettuce. Plant Dis. 89:317-324.

41. Vanachter, A., and Van Assche, C. 1970. The influence of soil temperature and moisture content on the effect of soil fumigants. Neth. J. Plant Pathol. 76:240-248.

42. Wang, D., and Yates, S. R. 1999. Spatial and temporal distributions of 1,3-dichloropropene in soil under drip and shank application and implications for pest control efficacy using concentration-time index. Pestic. Sci. 55:154160.

43. Warton, B., and Matthiessen, J. N. 2005. The crucial role of calcium interacting with soil $\mathrm{pH}$ in enhanced biodegradation of metam-sodium. Pest Manag. Sci. 61:856-862.

44. Warton, B., Matthiessen, J. N., and Roper, M. M. 2001. The soil organisms responsible for enhanced biodegradation of metham sodium. Biol. Fert. Soils 34:264-269.

45. Zhang, W. M., McGriffen, M. E., Jr., Becker, J. O., Ohr, H. D., Sims, J. J., and Campbell, S. D. 1998. Effect of soil physical factors on methyl odide and methyl bromide. Pestic. Sci. 53:7179. 